\title{
Pengaruh Struktur Modal terhadap Kinerja Perusahaan Pertanian yang terdaftar di Indeks Saham Syariah Indonesia
}

\author{
Suradi \\ Institut Agama Islam Negeri (IAIN) Bone \\ suradi1997iainbone@yahoo.co.id \\ Rusdiawan \\ Sekolah Tinggi Agama Islam (STAI) Al -Furqan Makassar \\ Rusdiawan9812@gmail.com
}

\begin{abstract}
This study discusses the effect of capital structure on the performance of agricultural companies listed in the Indonesian Islamic stock index. This study aims to determine how the influence of short-term debt and long-term debt (Short-term Debt and Longterm Debt) on company performance (Return on Assets, Return on Equity, Net Profit Margin). The results showed that long-term debt and short-term debt affect the company's performance, but the percentage of short-term debt and long-term debt can not be used as a measure to assess the company's performance is good or bad, because there are companies that have short and long-term debt but it is able to produce a fairly good performance, and vice versa when the short-term debt and long-term debt of the company has a high percentage does not guarantee the company will perform well. One of the things that makes the percentage of the company's capital structure does not significantly affect company performance is market share. This happened because at that time the market segmentation did not support the sale of the company's products, so the company could suffer losses (Profit Loss).
\end{abstract}

Keywords: Capital Structure, Agricultural Companies, Company Performance, Indonesian Islamic Stock Index.

\begin{abstract}
Abstrak
Penelitian ini membahas tentang pengaruh Struktur modal terhadap kinerja perusahaan pertanian yang terdaftar di indeks saham syariah Indonesia. Penelitian ini bertujuan untuk mengetahui bagaimana pengaruh utang jangka pendek dan
\end{abstract}

Jurnal Ilmiah Al Tsarwah 
utang jangka panjang (Short-term Debt dan Long-term Debt) terhadap kinerja perusahaan (Retur on Aset, Retur on Equity, Net Profit Margin). Hasil penelitian menunjukkan bahwa utang jangka panjang dan utang jangka pendek berpengaruh terhadap kinerja perusahaan akan tetapi persentase dari utang jangka pendek dan utang jangka panjang tidak bisa dijadikan ukuran untuk menilai kinerja perusahaan itu baik atau buruk, karena ada perusahaan yang utang jangka pendek dan jangka panjangnya sedikit namun mampu menghasilkan kinerja yang cukup baik, begitupun sebaliknya ketika utang jangka pendek dan utang jangka panjang perusahaan memiliki persentase yang tinggi tidak menjamin perusahaan akan berkinerja baik. Salah satu hal yang menjadikan persentase struktur modal perusahaan tidak secara signifikan mempengaruhi kinerja perusahaan adalah pangsa pasar. Hal ini terjadi karena pada saat itu segmentasi pasar tidak mendukung penjualan produk perusahaan, sehingga perusahaan bisa mengalami kerugian (Loss Profit).

Kata Kunci : Struktur Modal,Perusahaan Pertanian,Kinerja Perusahaan, Indeks Saham Syariah Indonesia .

\section{PENDAHULUAN}

Pertumbuhan perusahaan-perusahaan yang sangat pesat di indonesia dari tahun ke tahun mengindikasikan bahwa kegiatan bisnis semakin menarik bagi investor. Salah satu tempat yang paling diminati investor dalam melakukan investasi adalah pasar modal. Pasar modal adalah tempat para pihak khususnya perusahaan menjual saham (stock) dan obligasi (bond) dengan tujuan dari perusahaan tersebut nantinya akan dipergunakan sebagai tambahan dana untuk memperkuat modal perusahaan. ${ }^{1}$ Indonesia juga merupakan negara muslim terbesar di dunia sehingga Indonesia merupakan pasar yang sangat besar untuk pengembangan industri keuangan syariah. Investasi syariah di pasar modal merupakan hal yang cukup penting untuk meningkatkan pangsa pasar industri keuangan syariah di Indonesia.

${ }^{1}$ Irham Famhi, Rahasia Saham dan Obligasi: Strategi Meraih Keuntungan tak Terbatas dalam Bermain Saham dan Obligasi (Cet. I; Bandung: Alfabeta, 2013), h. 1. 
Keberadaan pasar modal di suatu negara bisa menjadi acuan untuk melihat tentang bagaimana kegairahan atau dinamisnya bisnis negara yang bersangkutan dalam menggerakkan berbagai kebijakan ekonominya seperti kebijakan fiskal dan moneter. ${ }^{2}$ Pasar modal bursa efek adalah pasar yang memperjual belikan surat-surat berharga jangka panjang. Bagi yang memerlukan modal maka bisa mendaftarkan dirinya sebagai emiten (peminjam modal). Emiten meminjam modal dengan cara menjual surat-surat berharga. ${ }^{3}$ Pada November 2007 Badan Pengawas Pasar Modal (BAPEPAM) dan Lembaga keuangan (LK) telah mengeluarkan Daftar Efek Syariah (DES) yang berisi nama-nama saham syariah yang ada di Indonesia, dengan adanya DES ini menjadi rujukan tentang daftar saham syariah di Indonesia serta memudahkan masyarakat untuk melihat saham-saham yang termasuk dalam saham syariah. Keberadaan DES ini kemudian ditindak lanjuti oleh BEI dengan meluncurkan Indeks saham Syariah Indonesia (ISSI) pada tangga. 12 Mei 2011.

Tabel Kapitalisasi Pasar Bursa efek Indonesia (Rp. Milyar)

\begin{tabular}{|c|c|c|}
\hline Tahun & $\begin{array}{c}\text { Jakarta Islamic } \\
\text { Indeks }\end{array}$ & $\begin{array}{c}\text { Indeks Saham Syariah } \\
\text { Indonesia }\end{array}$ \\
\hline 2000 & $74.268,92$ & - \\
\hline 2001 & $87.731,59$ & - \\
\hline 2002 & $92.070,49$ & - \\
\hline 2003 & $177.781,89$ & - \\
\hline 2004 & $263.863,34$ & - \\
\hline
\end{tabular}

${ }^{2}$ Irham Fahmi, Rahasia saham dan obligasi h. 1.

${ }^{3}$ Nurul Oktima, Kamus Ekonomi. Ed. 1(Cet. I; Surakarta: PT.Aksara Sinergi Media, 2012), h. 221.

Jurnal Ilmiah Al Tsarwah 


\begin{tabular}{|c|c|c|}
\hline 2005 & $395.649,84$ & - \\
\hline 2006 & $620.165,31$ & - \\
\hline 2007 & $1.105 .897,25$ & - \\
\hline 2008 & $428.525,74$ & - \\
\hline 2009 & $937.919,08$ & - \\
\hline 2010 & $1.134 .632,00$ & - \\
\hline 2011 & $1.141 .983,81$ & $1.968 .091,37$ \\
\hline 2012 & $1.671 .004,23$ & $2.451 .334,37$ \\
\hline 2013 & $1.672 .099,91$ & $2.557 .846,77$ \\
\hline 2014 & $1.944 .531,70$ & $2.946 .892,79$ \\
\hline 2015 & $1.737 .290,98$ & $2.600 .850,72$ \\
\hline 2016 Januari & $1.764 .358,85$ & $2.598 .203,24$ \\
\hline Februari & $1.833 .097,90$ & 2.689 .933 .17 \\
\hline Maret & $1.879 .354,35$ & $2.796 .012,59$ \\
\hline April & 1.881 .274 .28 & $2.824 .409,18$ \\
\hline Mei & $1.868 .586,38$ & $2.804 .579,10$ \\
\hline Juni & $1.964 .048,11$ & $3.029 .643,77$ \\
\hline Juli & $2.149 .426,09$ & $3.172 .188,14$ \\
\hline Agustus & $2.209 .364,54$ & $3.263 .156,93$ \\
\hline September & 2.215.379,04 & $3.256 .321,88$ \\
\hline Oktober & 2.024 .934 .53 & $3.127 .302,04$ \\
\hline November & $2.188 .781,13$ & $3.291 .469,29$ \\
\hline Desember & $2.041 .070,80$ & $3.175 .053,04$ \\
\hline
\end{tabular}

Sumber: Statistik Pasar Modal Syariah www.ojk.com, 2017 
Berdasarkan data dari Indeks Saham Syariah Indonesia ada beberapa perusahaan yang termasuk dalam emiten mereka dan salah satunya adalah perusahaan-perusahaan yang bergelut dalam bidang usaha pertanian. Berikut ini adalah daftar-daftar perusahaan yang terdaftar di ISSI dalam bidang pertanian

\section{Tabel . Daftar Nama Perusahaan Pertanian yang Terdaftar di ISSI}

\begin{tabular}{|c|c|c|}
\hline No. & Kode Saham & Nama Penerbit Efek \\
\hline 1 & AALI & PT. Astra Agro Lestari Tbk. \\
\hline 2 & ANJT & PT. Austindo Nusantara Jaya Tbk. \\
\hline 3 & BISI & PT. BISI Internasional Tbk. \\
\hline 4 & BTEK & PT. Bumi Teknokultura Unggul Tbk. \\
\hline 5 & DSFI & PT. Darma Samudera Fishing Industries \\
\hline 6 & GOLL & PTk. Golden Plantation Tbk. \\
\hline 7 & GZCO & PT. Gozco Plantations Tbk. \\
\hline 8 & IIKP & PT. Inti Agri Resources Tbk. \\
\hline 9 & LSIP & PT. PP London Sumatra Indonesia Tbk. \\
\hline 10 & MAGP & PT. Multi Agro Gemilang Plantation Tbk. \\
\hline 11 & PALM & PT. Providen Agro Tbk. \\
\hline 12 & SGRO & PT. Sampoerna Agro Tbk. \\
\hline 13 & SIMP & PT. Salim Ivomas Pratama Tbk. \\
\hline 14 & SSMS & PT. Sawit Sumbermas Sarana Tbk. \\
\hline
\end{tabular}

Sumber: www.idx.com, 2017

Berdasarkan data diatas indeks Saham Syariah pada sektor pertanian cukup diminati oleh para perusahaan-perusahaan besar di Indonesia. Setiap 
perusahaan yang melakukan kegiatan produksi baik itu barang ataupun jasa, karena dengan begitulah perusahaan dapat dinilai kinerjanya. Kinerja atau performanceapparaisaladalah proses dengan mana kinerja individual diukur dan dievaluasi ${ }^{4}$.

Modal sendiri merupakan sumber modal yang berasal dari pemilikan perusahaan. ${ }^{5}$ Modal adalah uang yang dipakai sebagai pokok (induk) untuk berdagang, melepas uang, dan sebagainya; harta benda (uang, barang, dan sebagainya) yang dapat dipergunakan untuk menghasilkan sesuatu yang menambah kekayaan dan sebagainya; barang digunakan sebagai dasar atau bekal untuk bekerja; sumber pembelajaran dari pemilik. ${ }^{6}$ Struktur modal sebagai variabel independen dalam penelitian ini diukur dengan tingkat utang perusahaan. Tingkat utang yang diukur dalam penelitian ini adalah rasio utang jangka pendek terhadap aset (Short-term Debt / STD), dan Rasio utang jangka Panjang (Long-term Debt / LTD). Sementara itu, Kinerja perusahaan sebagai variabel dependen dalam penelitian ini diukur dengan Returnon Aset (ROA), Retur on Equity (ROE), dan Net Profit Margin (NPM).Berdasarkan uraian latar belakang diatas, maka dapat ditarik rumusan masalah apakah utang jangka panjang dan utang jangka pendek berpengaruh terhadap kinerja perusahaan pertanian yang terdaftar di ISSI.

\section{METODE}

1. JenisPenelitian

${ }^{4}$ Wibowo, Manajemen kinerja, ed IV (Jakarta; Rajawali Pers, 2014). h 187.

5 Jumingan, Analisis laporan keuangan. Ed. 3 (Jakarta; PT. Bumi Aksara) h. 14.

${ }^{6}$ Nurul Oktima, Kamus Ekonomi. h. 197. 
Jenis penelitian inia dalah penelitian kualitatif. Creswll sebagaimana yang dikutip olehJuliansyah Noor, menyatakan bahwa penelitian kualitatif sebagai suatu gambaran kompleks, meneliti kata-kata, laporan terinci dari pandangan responden, dan melakukan studi pada situasi yang alami. ${ }^{7}$

\section{PendekatanPenelitian}

Pendekatan penelitian yang digunakan adalah pendekatan keilmuan yaitu pendekatan dengan menggunakan ilmu Ekonomi yaitudimana peneliti mengunakanalat analisis yang berkaitan dengan teori-teori ekonomi.

\section{Data dan Sumber Data}

Data adalah segala fakta dan angka yang dapat dijadikan bahan untuk menyusun suatu informasi ${ }^{8}$. Sumber data dalam penelitian ini adalah data yangdi olah berasal dari laporan keuangan masing-masing perusahaan, data ini merupakan data sekunder.Data sekunder ialah data yang diperoleh secara tidak langsung, terdiri dari dokumen-dokumen, surat, dokumen-dokumen resmi dari instansi pemerintah, laporan keuangan, dan lain sebagainya yang berupa arsip perusahaan. ${ }^{9}$ Data dalam penelitian ini diambil di Pasar Modal Syariah melalui websiteresmi

7Juliansayah Noor, MetodologiPenelitianSkripsi, Tesis, DisertasidanKaryallmiah, Ed. 1 (cet. V: Jakarta; Kencana, 2015), h. 34

${ }^{8}$ SuharsimiArikunto, Prosedur Penelitian : Suatu Pendekatan Praktik.,(Jakarta : Rineka Cipta, 2002), h. 96.

${ }^{9}$ S. Nasution, Metode Research; PenelitianIImiah, (Cet. III ; Jakarta : PT BumiAksara, 2000), h. 143. 
IDX ${ }^{10}$, OJK ${ }^{11}$, dan Yahoo Finance ${ }^{12}$. yaitu hasil laporan keuangan yang lengkap dari perusahaan pertanian di Indeks Saham Syariah Indonesia (ISSI) Beserta berbagai sumber buku, jurnal dan penelitian terdahulu yang mendukung penelitian.

\section{Teknik Pengumpulan Data}

Teknik pengumpulan data yang digunakan adalah dengan mengambil data dari basis yang merupakan pencatatan laporan keuangan tahunan pada perusahaan pertanian yang terdaftar di indeks saham syariah Indonesia yang terdaftar di BEl.

a. Dokumentasi

Dokumentasi menurut Irawan, sebagaimana yang dikutip oleh Sukandarrumidi dalam bukunya, ialah teknik pengumpulan data yang ditujukan kepada subjek penelitian. Dokumen dapat berupa catatan, buku, laporan kerja, arsip-arsip laporan keuangan, gambar, foto, video dan lain sebagainya. ${ }^{13}$ Wujud metode dokumentasi dalam penelitian ini yaitu berupa laporan keuangan dari perusahaan pertanian yang dipublikasikan pada situs www.idx.co.id.

b. StudiPustaka

${ }^{10}$ IDX singkatandari Indonesia Stock Exchange (Bursa Efek Indonesia) merupakantempatuntukmemperjualbelikanefek di Indonesia. Untukmendapatkan data melalui situs www.idx.co.id

${ }^{11}$ OJK singkatan dari Otoritas Jasa Keuangan, yaitu suatu lembaga yang menaungi dan mengawasi semua lembaga keuangan di Indonesia. Diakses melalui situs www.ojk.go.id.

${ }^{12}$ Yahoo Finance Indonesia digunakanuntukmendapatkan data hargaperusahaandalamlingkupharian, mingguan, bulanan, dantahunan, serta data mengenai index hargasahamgabungan (IHSG). Diaksesmelaluiwww.finance.yahoo.com

${ }^{13}$ Sukandarrumidi, MetodologiPenelitian (Cet. IV ; Yogyakarta : Gajah Mada University Press, 2012), h. 100-101. 
Metode studi pustaka digunakan untuk mengumpulkan data dengan melakukan penelusuran dari berbagai jenis kepustakaan untuk memperoleh berbagai teori, konsep, dalil-dalil, variabel, hubungan variabel, hasil-hasil penelitian terdahulu yang terkait dengan materi penelitian serta data-data sekunder sebagai langkah awal kegiatan penelitian. ${ }^{14}$

\section{HASIL PENELITIAN DAN PEMBAHASAN}

\section{Pengaruh Utang Jangka Pendek dan Utang jangka Panjang Terhadap Kinerja Perusahaan}

Tabel. Hasil Analisis Data

\begin{tabular}{|c|l|c|c|c|c|c|}
\hline \multirow{2}{*}{ No } & \multicolumn{1}{|c|}{$\begin{array}{c}\text { Nama } \\
\text { f }\end{array}$} & \multicolumn{2}{|c|}{ Struktur Modal } & \multicolumn{3}{|c|}{ Kinerja Perusahan } \\
\cline { 2 - 7 } 1. & $\begin{array}{l}\text { PT. Astra Agro } \\
\text { Lestari Tbk. }\end{array}$ & $13,08 \%$ & $22,27 \%$ & $3,21 \%$ & $4,96 \%$ & $12,84 \%$ \\
\hline 2. & $\begin{array}{l}\text { PT. Austindo } \\
\text { Nusantara Jaya } \\
\text { Tbk. }\end{array}$ & $8,57 \%$ & $23,88 \%$ & $1,75 \%$ & $2,59 \%$ & $20,31 \%$ \\
\hline 3. & $\begin{array}{l}\text { PT.BISI } \\
\text { Internasional } \\
\text { Tbk. }\end{array}$ & $12,47 \%$ & $14,59 \%$ & $13,91 \%$ & $16,29 \%$ & $41,82 \%$ \\
\hline 4. & $\begin{array}{l}\text { PT. Bumi } \\
\text { Teknokultura } \\
\text { Unggul Tbk. }\end{array}$ & $22,57 \%$ & $46,46 \%$ & $0,046 \%$ & $0,14 \%$ & $0,30 \%$ \\
\hline 5. & $\begin{array}{l}\text { PT. Darma } \\
\text { Samudera } \\
\text { Fishing } \\
\text { Industries Tbk. }\end{array}$ & $37,17 \%$ & $17,52 \%$ & $1,74 \%$ & $3,86 \%$ & $10,6 \%$ \\
\hline
\end{tabular}

${ }^{14}$ S. Nasution, Metode ..., h. 15. 


\begin{tabular}{|l|l|c|c|c|c|c|}
\hline 6. & $\begin{array}{l}\text { PT. Golden } \\
\text { Plantation Tbk. }\end{array}$ & $7,32 \%$ & $51,69 \%$ & $0,33 \%$ & $0,82 \%$ & $18,85 \%$ \\
\hline 7. & $\begin{array}{l}\text { PT. Gozco } \\
\text { Plantations Tbk. }\end{array}$ & $6,43 \%$ & $59,60 \%$ & $-43,63 \%$ & $-138,85 \%$ & $-284 \%$ \\
\hline 8. & $\begin{array}{l}\text { PT. Inti Agri } \\
\text { Resources Tbk. }\end{array}$ & $19,31 \%$ & $3,89 \%$ & $-7,55 \%$ & $-9,83 \%$ & $-32,3 \%$ \\
\hline 9. & $\begin{array}{l}\text { PT. PP London } \\
\text { Sumatra } \\
\text { Indonesia Tbk. }\end{array}$ & $8,22 \%$ & $10,87 \%$ & $6,24 \%$ & $7,75 \%$ & $15,40 \%$ \\
\hline 10. & $\begin{array}{l}\text { PT. Multi Agro } \\
\text { Gemilang } \\
\text { Plantation Tbk. }\end{array}$ & $17,99 \%$ & $13,03 \%$ & $-0,90 \%$ & $-1,31 \%$ & $-882,4 \%$ \\
\hline 11. & $\begin{array}{l}\text { PT. Providen } \\
\text { Agro Tbk. }\end{array}$ & $8,55 \%$ & $31,18 \%$ & $5,67 \%$ & $9,41 \%$ & $18,73 \%$ \\
\hline 12. & $\begin{array}{l}\text { PT. Sampoerna } \\
\text { Agro Tbk. }\end{array}$ & $17,22 \%$ & $37,64 \%$ & $5,51 \%$ & $12,22 \%$ & $15,75 \%$ \\
\hline 13. & $\begin{array}{l}\text { PT. Salim } \\
\text { Ivomas Pratama } \\
\text { Tbk. }\end{array}$ & $14,12 \%$ & $31,72 \%$ & $1,87 \%$ & $3,46 \%$ & $4,19 \%$ \\
\hline 14. & $\begin{array}{l}\text { PT. Sawit } \\
\text { Sumbermas } \\
\text { Sarana Tbk. }\end{array}$ & $18,35 \%$ & $33,43 \%$ & $8,25 \%$ & $17,13 \%$ & $21,73 \%$ \\
\hline
\end{tabular}

Sumber: Data Sekunder diolah, 2016.

Pada perusahaan PT. Astra Agro Lestari Tbk.Berdasarkan hasil laporan keuangan tahun 2016 yang telah diolah, struktur modal perusahaan (Shortterm Debt)sebesar 13,08\% dan (Long-term Debt) sebesar 22,27\% sedangkan kinerja perusahaan (Retur on Asset)mencapai 3,21\%, (Retur on Equity) mencapai 4,96\%, dan (Net Profit Margin) mencapai 12,84\%. Ini menandakan bahwa perusahaan pada tahun 2016 memiliki kinerja yang baik karena di tunjang dengan Struktur modal yang cukup serta segmentasi pasar yang baik.

Pada perusahaan PT. Austindo Nusantara Jaya Tbk.Berdasarkan hasil laporan keuangan tahun 2016 yang telah diolah, struktur modal perusahaan (Short-term Debt) sebesar 8,57\% dan (Long-term Debt) sebesar 22,88\% 
sedangkan kinerja perusahaan (Retur on Asset) mencapai1,75\%, (Retur on Equity) mencapai2,59\%, dan (Net Profit Margin) mencapai 20,31\%. Ini menandakan bahwa perusahaan pada tahun 2016 memiliki kinerja yang baik karena di tunjang dengan Struktur modal yang cukup serta segmentasi pasar yang baik.

Pada perusahaan PT. BISI Internasional Tbk. Berdasarkan hasil laporan keuangan tahun 2016 yang telah diolah, struktur modal perusahaan (Shortterm Debt) sebesar 12,47\% dan (Long-term Debt) sebesar 14,59\% sedangkan kinerja perusahaan (Retur on Asset) mencapai13,91\%, (Retur on Equity) mencapai16,29\%, dan (Net Profit Margin) mencapai 41,82\%. Ini menandakan bahwa perusahaan pada tahun 2016 memiliki kinerja yang baik karena di tunjang dengan Struktur modal yang cukup serta segmentasi pasar yang baik.

Pada perusahaan PT. Bumi Teknokultura Unggul Tbk. Berdasarkan hasil laporan keuangan tahun 2016 yang telah diolah, struktur modal perusahaan (Short-term Debt) sebesar 22,57\% dan (Long-term Debt) sebesar 46,46\% sedangkan kinerja perusahaan (Retur on Asset)hanya memperoleh 0,046\%, (Retur on Equity)hanya 0,14\%, dan (Net Profit Margin)hanya 0,30\%. Ini menandakan bahwa perusahaan pada tahun 2016 memiliki kinerja yang kurang baik, walaupun memiliki struktur modal yang dimiliki cukup tinggi namun segmentasi pasar tidak mendukung, sehingga perusahaan pada tahun 2016 hampir mengalami kerugian.

Pada perusahaan PT. Darma Samudera Fishing Industries Tbk. Berdasarkan hasil laporan keuangan tahun 2016 yang telah diolah, struktur modal perusahaan (Short-term Debt) sebesar 37,17\% dan (Long-term Debt) sebesar 17,52\% sedangkan kinerja perusahaan (Retur on Asset) mencapai 13,91\%, (Retur on Equity) mencapai 3,86\%, dan (Net Profit Margin) mencapai10,6\%. Ini menandakan bahwa perusahaan pada tahun 2016 
memiliki kinerja yang baik karena di tunjang dengan Struktur modal yang cukup serta segmentasi pasar yang baik.

Pada perusahaan PT. Golden Plantation Tbk. Berdasarkan hasil laporan keuangan tahun 2016 yang telah diolah, struktur modal perusahaan (Short-term Debt) sebesar 7,32\% dan (Long-term Debt) sebesar 51,69\% sedangkan kinerja perusahaan (Retur on Asset) mencapai $0,33 \%$, (Retur on Equity) mencapai 0,82\%, dan (Net Profit Margin) mencapai 18,85\%. Ini menandakan bahwa perusahaan pada tahun 2016 memiliki kinerja yang baik karena di tunjang dengan Struktur modal yang cukup walaupun dapat kita lihat segmentasi pasar tidak terlalu mendukung, namun perusahaan mampu mengatasinya sehingga tidak mengalami kerugian.

Pada perusahaan PT. Gozco Plantations Tbk.. Berdasarkan hasil laporan keuangan tahun 2016 yang telah diolah, struktur modal perusahaan (Short-term Debt) sebesar 6,43\% dan (Long-term Debt) sebesar 59,60\% sedangkan kinerja perusahaan mengalami lossProfit(Retur on Asset) menjadi -43,63\%, (Retur on Equity) $-138,85 \%$, dan (Net Profit Margin) hanya 284\%. Ini menandakan bahwa perusahaan pada tahun 2016 memiliki kinerja yang tidak baik, walaupun memiliki struktur modal yang dimiliki cukup tinggi namun segmentasi pasar tidak mendukung, sehingga perusahaan pada tahun 2016 perusahaan mengalami kerugian.

Pada perusahaan PT. Inti Agri Resources Tbk.. Berdasarkan hasil laporan keuangan tahun 2016 yang telah diolah, struktur modal perusahaan (Short-term Debt) sebesar 19,31\% dan (Long-term Debt) sebesar 3,89\% sedangkan kinerja perusahaan mengalami lossProfit(Retur on Asset) memperoleh -7,55 \%, (Retur on Equity) memperoleh-9,83\%, dan (Net Profit Margin) memperoleh-32,3\%. Ini menandakan bahwa perusahaan pada tahun 2016 memiliki kinerja yang kurang baik, walaupun memiliki struktur modal 
yang dimiliki cukup baik namun segmentasi pasar tidak mendukung, sehingga perusahaan pada tahun 2016 mengalami kerugian.

Pada perusahaan PT. PP London Sumatra Indonesia Tbk.. Berdasarkan hasil laporan keuangan tahun 2016 yang telah diolah, struktur modal perusahaan (Short-term Debt) sebesar 8,22\% dan (Long-term Debt) sebesar 10,87\% sedangkan kinerja perusahaan (Retur on Asset) mencapai 6,24\%, (Retur on Equity) mencapai 7,75\%, dan (Net Profit Margin) mencapai 15,40\%. Ini menandakan bahwa perusahaan pada tahun 2016 memiliki kinerja yang baik karena di tunjang dengan Struktur modal yang cukup serta segmentasi pasar yang baik.

Pada perusahaan PT. Multi Agro Gemilang Plantation Tbk. Berdasarkan hasil laporan keuangan tahun 2016 yang telah diolah, struktur modal perusahaan (Short-term Debt) sebesar 17,99\% dan (Long-term Debt) sebesar $13,03 \%$ sedangkan kinerja perusahaan mengalami lossProfit (Retur on Asset) memperoleh - $0,90 \%$, (Retur on Equity) memperoleh $-1,31 \%$, dan (Net Profit Margin) memperoleh -882,4\%. Ini menandakan bahwa perusahaan pada tahun 2016 memiliki kinerja yang buruk, walaupun memiliki struktur modal yang dimiliki cukup baik namun segmentasi pasar tidak mendukung, sehingga perusahaan pada tahun 2016 mengalami kerugian yang cukup besar.

Pada perusahaan PT. Providen Agro Tbk. Berdasarkan hasil laporan keuangan tahun 2016 yang telah diolah, struktur modal perusahaan (Shortterm Debt) sebesar 8,55\% dan (Long-term Debt) sebesar 31,18\% sedangkan kinerja perusahaan (Retur on Asset) mencapai 5,67\%, (Retur on Equity) mencapai 9,41\%, dan (Net Profit Margin) mencapai 18,73\%. Ini menandakan bahwa perusahaan pada tahun 2016 memiliki kinerja yang baik karena di tunjang dengan Struktur modal yang cukup serta segmentasi pasar yang baik. 
Pada perusahaan PT. Sampoerna Agro Tbk. Berdasarkan hasil laporan keuangan tahun 2016 yang telah diolah, struktur modal perusahaan (Short-term Debt) sebesar 17,22\% dan (Long-term Debt) sebesar 37,64\% sedangkan kinerja perusahaan (Retur on Asset) mencapai 5,67\%, (Retur on Equity) mencapai 12,22\%, dan (Net Profit Margin) mencapai 15,75\%. Ini menandakan bahwa perusahaan pada tahun 2016 memiliki kinerja yang baik karena di tunjang dengan Struktur modal yang cukup serta segmentasi pasar yang baik.

Pada perusahaan PT. Salim Ivomas Pratama Tbk. Berdasarkan hasil laporan keuangan tahun 2016 yang telah diolah, struktur modal perusahaan (Short-term Debt) sebesar 14,12\% dan (Long-term Debt) sebesar 31,72\% sedangkan kinerja perusahaan (Retur on Asset) mencapai 1,87\%, (Retur on Equity) mencapai 3,46\%, dan (Net Profit Margin) mencapai 4,19\%. Ini menandakan bahwa perusahaan pada tahun 2016 memiliki kinerja yang baik karena di tunjang dengan Struktur modal yang cukup serta segmentasi pasar yang baik.

Pada perusahaan PT. Sawit Sumbermas Sarana Tbk. Berdasarkan hasil laporan keuangan tahun 2016 yang telah diolah, struktur modal perusahaan (Short-term Debt) sebesar 18,35\% dan (Long-term Debt) sebesar 33,42\% sedangkan kinerja perusahaan (Retur on Asset) mencapai 8,25\%, (Retur on Equity) mencapai 17,13\%, dan (Net Profit Margin) mencapai 21,73\%. Ini menandakan bahwa perusahaan pada tahun 2016 memiliki kinerja yang baik karena di tunjang dengan Struktur modal yang cukup serta segmentasi pasar yang baik.

Berdasarkan hasil analisis diatas dapat dilihat bahwa tingkat fluktuatif dari struktur modal pada setiap perusahaan bisa mempengaruhi kinerja dari perusahaan tersebut. Namun besar atau kecilnya persentase dari struktur modal tidak menunjukkan bahwa kinerja perusahaan meningkat ataupun 
menurun, sehingga sebuah perusahaan yang memiliki utang jangka pendek dan utang jangka panjang yang tinggi tidak selamanya mampu menghasilkan kinerja yang buruk, begitu pun sebaliknya ketikan perusahaan memiliki utang jangka pendek dan utang jangka panjang yang rendah tidak selamanya kinerjanya baik.Sebagai contohnya pada perusahaan PT. Multi Agro Gemilang Plantation yang memiliki struktur modal yang cukup baik yakni Short term Debt 17,99\%, Long term Debt 13.03, namun memiliki kinerja perusahaan yang tidak terlalu baik yakni Return on Aset -0,90\%, Retur non Equity $-1,31 \%$ dan Net Profit Margin -882,4\%.

Kinerja perusahaan bukan hanya di pengaruhi oleh struktur modal, salah satu hal yang berpengaruh cukup besar pada kinerja perusahaan adalah kondisi pasar. Karena di mana kondisi pasar yang mendukung maka hasil kinerja perusahaan akan bernilai positif, akan tetapi jika kondisi pasar tidak mendukung maka dapat dipastikan perusahaan akan mendapatkan kerugian atau loss Profit.

\section{KESIMPULAN DAN SARAN}

\section{Kesimpulan}

Perusahaan pertanian yang telah terdaftar pada Indeks Saham Syariah Indonesia (ISSI), yang memiliki struktur modal dalam hal ini utang jangka pendek dan utang jangka panjang (Short-term Debt dan Short-term Debt) tidak secara signifikanmempengaruhi kinerja perusahaan(Retur on Aset, Retur on Equity, dan Net Profit Margin), karena terkadang ketika jumlah struktur modal yang cukup besar, perusahaan juga bisa mengalami kerugian (Loss Profit). Hal ini terjadi karena pada saat itu segmentasi pasar tidak mendukung penjualan dari produksi perusahaan.

\section{Saran}


Berdasarkan kesimpulan diatas maka dapat disarankan bagi para manajer keuangan agar mampu melihat kondisi pasar, sebelum memutuskan untuk mengambil utang jangka pendek ataupun utang jangka panjang. karena risiko yang akan ditanggung ketikan mengambil utang jangka panjang/pendek, namun segmentasi pasar tidak mendukung maka akan membuat kinerja dari perusahaan akan menurun dan dapat menyebabkan kerugian (Loss Profit).

\section{DAFTAR PUSTAKA}

Arikunto, Suharsimi. Prosedur Penelitian: Suatu Pendekatan Praktik. Jakarta: Rineka Cipta, 2002.

Bungin, Burhan. Metodologi Penelitian Sosial \& Ekonomi: Format-Format Kauantitatif dan Kualitatif untuk Studi Sosiologi, Kebijakan Publik, Komunikasi, Manajeman, dan Pemasaran. Cet. I. Jakarta: Kencana, 2013.

Famhi, Irham. Rahasia Saham dan Obligasi: Strategi Meraih Keuntungan tak Terbatas dalam Bermain Saham dan Obligasi. Cet. I. Bandung: Alfabeta, 2013.

------. Pengantar Manajemen Keuangan Teori dan Soal Jawab. Cet. III. Bandung: CV. ALFABETA, 2013.

IDX singkatan dari Indonesia Stock Exchange (Bursa Efek Indonesia) merupakan tempat untuk memperjualbelikan efek di Indonesia. Untuk mendapatkan data melalui situs www.idx.co.id

Jumingan. Analisis laporan keuangan. Ed. 3. Jakarta; PT. Bumi Aksara.

KBBI Online di akses pada 20 agustus 207 pkl. 0.40 Wita.

Masfufah, "Analisis Struktur Modal Terhadap Kinerja Keuangan Studi Kasus Pada Perusahaan Farmasi Yang Terdaftar Di Bei Periode 2008-2014". Skripsi Universitas Hasanuddin, Makassar, 2016.

Nasution. S. Metode Research; Penelitian IImiah. Cet. III; Jakarta: PT Bumi Aksara, 2000.

Jurnal Ilmiah Al Tsarwah 236 
Noor, Juliansayah. Metodologi Penelitian Skripsi, Tesis, Disertasi dan Karya IImiah. Ed. 1 Cet. 5. Jakarta; Kencana, 2015.

Nurmadi. Rusman "Analisis Faktor-Faktor Yang Mempengaruhi Struktur Modal Perusahaan Manufaktur". Jurnal Keuangan dan Bisnis. Vol. 5, No. 2, Juli 2013.

OJK singkatan dari Otoritas Jasa Keuangan, yaitu suatu lembaga yang menaungi dan mengawasi semua lembaga keuangan di Indonesia. Diakses melalui situs www.ojk.go.id.

Oktima, Nurul. Kamus Ekonomi. Ed.1 Cet. I. Surakarta: PT.Aksara Sinergi Media, 2012.

Prastowo, Andi. Metode Penelitian Kualitatif dalam Perspektif Rancangan Penelitian Cet. III. jogjakarta: AR-RUZZ MEDIA, 2016.

Priyatno, Dwi. Mandiri Belajar PASW: Statistical Product and Service Solution, Cet. II. Jakarta: PT.Buku Kita, 2008.

Rosidah, dan Ambar T. Sulistiyani Manajemen Sumber Daya Manusia, Yogyakarta: Graha Ilmu, 2003.

Setyaningrum. Dwi "Analisis Struktur Modal Terhadap Kinerja Perusahaan pada Perusahaan Otomotif yang Terdaftar di BEI Tahun 2008-2012". Skripsi, Program Studi Manajemen Fakultas Ekonomi dan Bisnis Universitas Muhammadiyah, Surakarta, 2015.

Siregar, Syofian. Statistik Deskriptif Untuk Penelitian. Cet. 1 Jakarta: PT RajaGrafindo Persada, 2010.

Sukandarrumidi. Metodologi Penelitian Cet. XIV. Yogyakarta: Gajah Mada University Press, 2012.

Supardi. Kinerja Guru, ed. 1. Jakarta; rajawali pers. 2014.

Tim Penyusun Pusat Bahasa. Kamus besar bahasa Indonesia, ed. 3. Cet. III. Jakarta; Balai Pustaka, 2005.

Wibowo. Manajemen kinerja, ed. IV. Jakarta; Rajawali Pers, 2014.

Yahoo Finance Indonesia digunakan untuk mendapatkan data harga perusahaan dalam lingkup harian, mingguan, bulanan, dan tahunan, serta data mengenai index harga saham gabungan (IHSG). Diakses melalui www.finance.yahoo.com 
Jurnal Ilmiah Al Tsarwah

Program Magister Program Studi Ekonomi Syariah

Institut Agama Islam Negeri (IAIN) Bone 